УДК 81'42-028.46(41)

DOI: 10.18523/2616-8502.2019.2.20-29

Pavlo Zernetsky

https://orcid.org/0000-0003-4952-0747

Ganna Riabokon

https://orcid.org/0000-0001-5796-7800

\title{
ORGANIZATIONAL STRUCTURE OF BRITISH PARLIAMENTARY DISCOURSE: PRAGMALINGUISTIC ASPECT
}

The article investigates the peculiarities of utterance construction in British Parliamentary Discourse from the positions of pragmalinguistics. For the basis of the research, the authors take the classification of speech acts by J. Austin and J. Searle combined with the model for spoken discourse analysis by J. Sinclair and M. Coulthard and apply it for the description of the constituent components of speech moves (PreHead, Head, and Post-Head) in speech activity of the main participants of British Parliamentary Debates. The authors define pragmatic intentions of the speakers and describe the models of Speech Moves progressions in terms of Pre-Head, Head, and Post-Head ties, which provides the insight into the way the speakers build the utterances in order to realize their speech intentions.

Keywords: pragmatics, speech act, speech move, speech transaction, speech event, illocutionary force, Pre-Head, Head, Post-Head.

\section{Introduction}

One of the central aspects of pragmatics study is the realization of communicative intention by the participants of discourse. At the beginning of its foundation and development, the early pragmalinguistic research tended to concentrate on the construction, purpose, and functioning of isolated utterances (Austin, 1986; Searle, 1986a; Searle, 1986b; Frazer, 1975; Karaban, 1989; Pocheptsov, 1986). Contrary to this approach, but enhanced with the methodology and inventory of that trend, modern pragmalinguistics is based on the analysis of discourse in its coherent and cohesive architectonics, or semiotic continuum (Sinclair, Coulthard, 1992; van Dijk, 1997; Serazhym, 2002). In the process of discourse developing, the speakers refer to the pool of available means of utterance construction so that the pragmatic intention realized through the illocutionary force sounded most convincingly and effectively for the audience it is intended to. Strong and comprehensive expression of ideas is especially important in political discourse which is primarily based on speech influence. The topicality of the research is stipulated by the fact that the article concentrates on communicative functional approach to discourse analysis, viz. analyzing the tactical moves of speech activity and thus trespasses the boundaries of traditional theoretical pragmatics and employs theories and methods applied in the sphere of studying language in a wider socio-cultural context. The authors set the tasks to analyze the architectonics of speech activity intrinsic to British Parliament, investigate the composition and nature of speech moves, define speech intentions and correlate them with appropriate speech acts, and by means of quantitative analysis determine the frequency of their usage in general picture of discourse.

\section{Results and discussion}

The communicative functional approach to discourse analysis first of all presupposes the four semiotic dimensions in the analysis of a text within its pragmatic, semantic, sigmatic, and syntactic dimensions (boundaries). Communicatively oriented deciphering of the text as an informational trace of discourse envisages pragmatic discourse analysis of speech activity units in their rank scale: Speech Acts (SA), Speech Moves (SM), and Speech Transactions (ST), and finally, Speech Event (SE), which constitute the hierarchical pragmatic structure of discourse. In terms of text organization, SE, being the highest rank, presents 
a session in the Parliament taking place on a particular date; STs can be referred as macro-topics of discourse because hearings in the Parliament involve discussing different matters within one session; SMs make its micro-topics and correspond to stretches of speech by one of the speakers (utterance) in a occursive discourse (dialogue) or a paragraph in cumulative (monologue) discourse. According to general hierarchical structure where the components of the lower level form those of higher ones, within each SM which gives initial understanding of the micro-topic of the discourse, it is possible to distinguish between its immediate constituents consisting of topical and issuing SAs which make the lowest, smallest and most elementary ranks of discourse.

British Parliamentary discourse as one of the principal in British political discourse genres easily undergoes the procedure of classical conversational pragmatic discourse analysis developed by J. Sinclair and M. Coulthard in 1975 for the analysis of classroom discourse in the process of language teaching. Parliamentary discourse resembles the classroom one in the way that both are run according to formally structured rules and controlled by the dominant party which is presented by a teacher in classroom interlocution or the Speaker in case of Parliamentary debates (Sinclair \& Coulthard, 1992, p. 34). Under Parliamentary discourse we understand all genres possible for realization by the main participants of the debates - Speaker, Members of Parliament, and Members of Government - within typical parliamentary procedure in the Houses of Commons of
British Parliament. However, the development of classroom conversations offers little space for improvisation and usually develops according to the pre-set scenario: the teacher knows the answer and just wants to elicit the same right answer from the students. Contrary to this, parliamentary discourse promises much wider scope of exploration in terms of pragmatic senses and semantic meanings and the ways of syntactic and stylistic realizations because the speech exchanges are impromptu, albeit proceed in the frameworks of the discussed topic according to the agenda, and allow the speakers to employ a full range of language and subject thesaurus.

Applying the J. Sinclair and M. Coulthard model for the discourse analysis of Parliamentary debates, it is possible to distinguish between SEs which correspond to the discussed topic within the agenda, ST that comprises a question and proceeding answer/answers, SM that is the (extended) question or answer, and, finally, SA which realizes the immediate intention of a speaker to perform a certain act of asking, informing, promising, warning, etc. The J. Sinclair and M. Coultdard model suggests that each SM in a conversation can be analyzed in terms of its Pre-Head, Head, and Post-Head components consisting of one/several SAs. For the basis of SA description, we take the classification of SAs by J. Searle (1969) and as a supplementary inventory for such analysis, we suggest the classification of SAs by P. Zernetsky and developed informationally-oriented classification of SAs by P. Zernetsky and G. Riabokon (Riabokon, 2005, p. 220) illustrated in Table 1.

Table 1

\section{Informationally-Oriented Classification} of Speech Acts

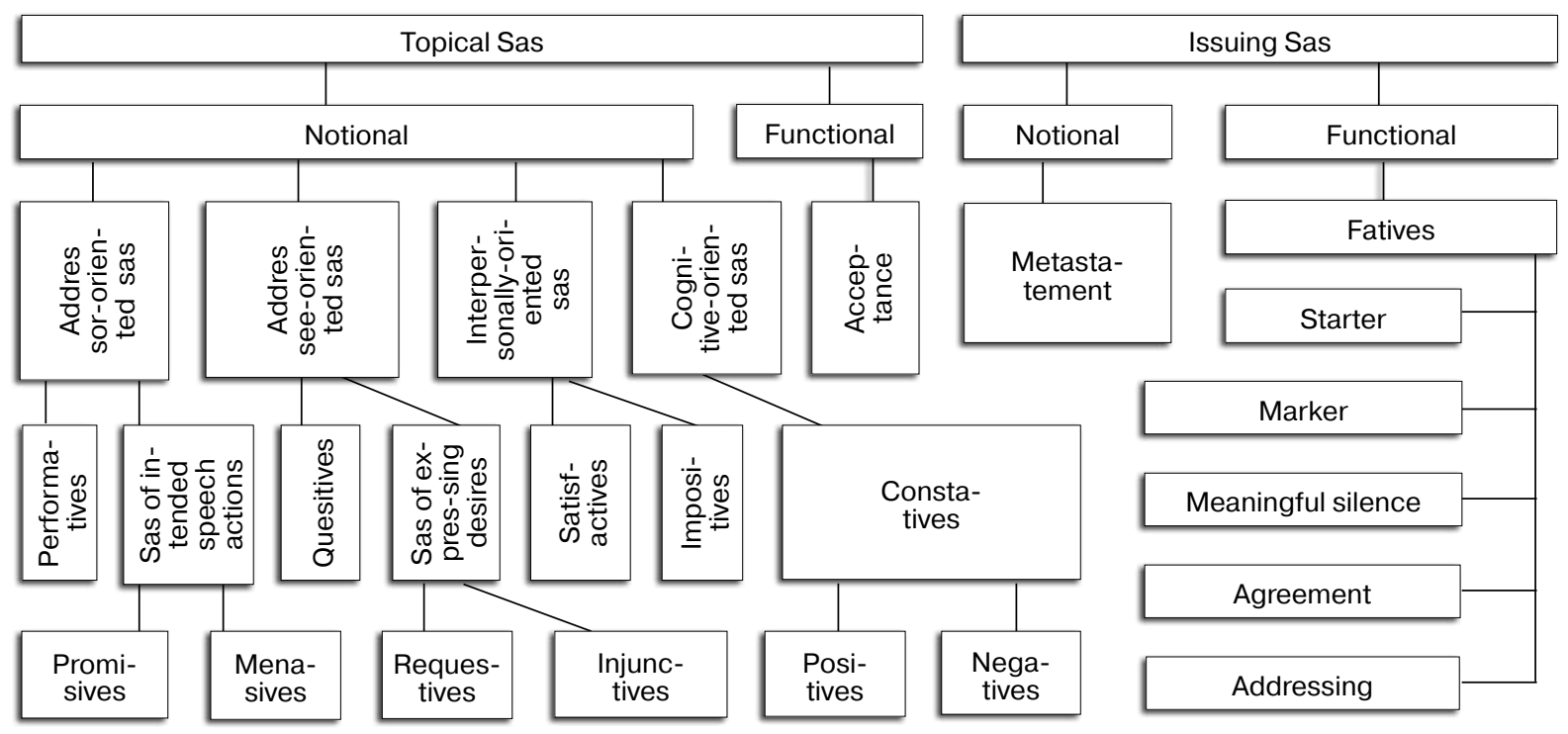


According to the informationally-oriented classification of SAs, on the first level of division, they are classified into Topical and Issuing SA both of which are further subdivided into Notional that provide an actual pragmatic sense - e.g. to inform, to ask, to request, to perform a speech action (apologize, congratulate, proclaim, etc) - and Functional that regulate, or furnish, speech activity. The extended informationally-oriented classification of SAs by P. Zernetsky and G. Riabokon (Riabokon, 2005, p. 220) also implies the division according to binary opposition where each class of SAs undergoes the division into negative and positive representation of virtually the same speech intention. On this stage, within the class of Constatives, it is possible to distinguish between Positives (approval) and Negatives (disapproval); the class of expressing desires splits into Requestives and Injunctives (orders, commands); similarly, the class of intended speech actions is presented by Promisives and Menasives. Thus the binary opposition greatly facilitates cognitive perception of speech activity according to the variety of its pragmatic intentions.
Departing from the general statement that structurally SMs include three divisional stages, that is Pre-Head, Head, and Post-Head, each of which can comprise a number of SAs that realize immediate pragmatic intention of a speaker. According to the presence of its components, SMs can be mono-componential, i.e. consisting of a single component typically, a nuclear component, that is a Head - or poly-componential, those including Pre-Head and/ or Post-Head (non-nuclear components). Within each divisional stages, it is possible to distinguish between mono-headed components that consist of homogeneous SAs (e.g. Constative + Constative) or poly-headed, those of heterogeneous composition (e.g. Constative + Quesitive). Here we present an extended table that combine classification by common immediate pragmatic intentions described by J. Sinclair and M. Coulthard (1991, p. 15) supplemented with corresponding SAs. Such structure fully corresponds to pragmatic norms of speech activity within the Parliamentary procedure in the House of Commons and will be employed in further analysis of STs and their constituting elements, SMs and SAs:

Speech Moves and Their Discourse Functions

\begin{tabular}{|l|l|l|}
\hline \multicolumn{1}{|c|}{ Speech intention } & \multicolumn{1}{c|}{ Speech act } & \multicolumn{1}{c|}{ Discourse function } \\
\hline Acceptance & fative & Indicates agreement to a request, suggestion, etc \\
\hline Acknowledgement & fative & Signals receipts of information \\
\hline Agreement & constative, fative & Signals agreement with what was said \\
\hline Answer & constative & Responds to a question, request \\
\hline Confirmation & constative, fative & Responds to a request for confirmation \\
\hline Disagreement & constative (negative) & Expresses disagreement \\
\hline Evaluation & constative & Judges the value of what the previous speaker said \\
\hline Informing & constative & Provides information \\
\hline Inviting & quesitive, requestive & Asks for agreement / suggests doing something \\
\hline Questioning & quesitive & Asks for information, confirmation, clarification \\
\hline Replaying & constative & Responds to a statement \\
\hline Request & requestive, injunctive & Asks / demands somebody to do something \\
\hline $\begin{array}{l}\text { Statements: } \\
\text { - allegation } \\
\text { - clarification } \\
\text { - concession }\end{array}$ & $\begin{array}{l}\text { meta-statement } \\
\text { constative } \\
\text { accusative } \\
\text { constative } \\
\text { constative } \\
\text { constative } \\
\text { marker, } \\
\text { starter } \\
\text { constative } \\
\text { constative }\end{array}$ & $\begin{array}{l}\text { Informs or expresses opinion } \\
\text { Indicates someone's fault }\end{array}$ \\
\hline
\end{tabular}


The extract of discourse in Example 1 illustrates the ST of the discussion on Universal Credit on 9 October 2017 in the House of Commons of British Parliament. This piece of discourse develops according to a typical occusive structure of debates when the representatives of state power are questioned by the Members of Parliament re- garding their activity. This ST involves all three discursive roles within the procedure of parliamentary debates which according to its genre specifics imply the polylogue of its main participants: the Speaker, Members of Parliament, and representatives of state power (Zernetsky \& Riabokon, 2014, p. 57):

Example 1

\begin{tabular}{|c|c|c|}
\hline$\sum_{\infty}$ & $\begin{array}{l}\text { Hywel Williams (Arfon) (PC): What progress he is making on the roll- } \\
\text { out of universal credit (question) }\end{array}$ & $\begin{array}{l}\text { SM1: (questioning) Head1 }\{\text { Quesi- } \\
\text { tive1\} }\end{array}$ \\
\hline$\sum_{\infty}^{N}$ & $\begin{array}{l}\text { The Secretary of State for Work and Pensions (Mr David Gauke): The } \\
\text { roll-out of universal credit is proceeding to plan, gradually and sensi- } \\
\text { bly (answer). People are moving into work faster and staying in work } \\
\text { for longer. The most recent phase of expansion will only take the pro- } \\
\text { portion of the forecast claimant population receiving universal credit } \\
\text { from } 8 \% \text { currently to } 10 \% \text { by the end of January (substantiation) }\end{array}$ & $\begin{array}{l}\text { SM2: (answer) Head2 } \text { \{Constative } \\
2.1\}+(\text { substantiation) Post-Head2 } \\
\{\text { Constative } 2.2+\text { Constative } 2.3\}\end{array}$ \\
\hline$\sum_{\infty}^{\infty}$ & $\begin{array}{l}\text { Hywel Williams: There is a great deal of support for the principles of } \\
\text { universal credit (agreement). However, the roll-out has been charac- } \\
\text { terized as "operationally messy, socially unfair and unforgiving" (in- } \\
\text { forming). These are not my words, but those of Sir John Major (refer- } \\
\text { ence). If the Secretary of State will not postpone the roll-out-along with } \\
\text { many other right hon. and hon. Members, I would like him to consider } \\
\text { that again (inviting)-will he consider two other remedies: to drop the } \\
\text { waiting period, and to allow the benefit to be paid fortnightly? (re- } \\
\text { questing) }\end{array}$ & $\begin{array}{l}\text { SM3: (agreement) Pre-Head3 } \\
\{\text { Constative } 3.1\}+(\text { infor- } \\
\text { ming }+ \text { reference }) \text { Head3 }\{\text { Consta- } \\
\text { tive } 3.2+\text { Constative } 3.3\}+(\text { invi- } \\
\text { ting }+ \text { requesting) Post-Head3 } \\
\text { \{Requestive } 3.1+\text { Requestive } 3.2\}\end{array}$ \\
\hline$\sum_{\infty}^{D}$ & $\begin{array}{l}\text { Mr Gauke: Let me be clear: as I touched on earlier, the evidence so } \\
\text { far shows that those who go on to universal credit are more likely to } \\
\text { be working six months later than they would be had they been on the } \\
\text { legacy benefits, and they are also more likely to be progressing in work } \\
\text { (clarification). That is really important, and it is not something that } \\
\text { I want to deny people. I believe that we should roll out something like } \\
\text { this gradually and sensibly, and make changes as and when necessary, } \\
\text { but that is exactly what we are doing (statement) }\end{array}$ & $\begin{array}{l}\text { SM4: (clarification) Pre-Head4 } \\
\text { \{Meta-statement } 4.1\}+(\text { statement }) \\
\text { Head4 }\{\text { Constative } 4.1+\text { Consta- } \\
\text { tive } 4.2\}\end{array}$ \\
\hline$\sum_{\infty}^{n}$ & $\begin{array}{l}\text { Mohammad Yasin: A recently bereaved constituent of mine, a work- } \\
\text { ing single parent, has seen her income reduced by £300 a month since } \\
\text { transferring to universal credit (informing). For her, work does not } \\
\text { pay. Will the Secretary of State urgently review the link between agree- } \\
\text { ment to support payments and universal credit, and will he stop the } \\
\text { roll-out until he has done so? (questioning) }\end{array}$ & $\begin{array}{l}\text { SM5: (informing) Pre-Head5 } \\
\text { \{Constative 5.1+ Constative 5.2\} }+ \\
\text { (questioning) Head5 }\{\text { Quesi- } \\
\text { tive } 5.1\}\end{array}$ \\
\hline$\sum_{\infty}^{b}$ & $\begin{array}{l}\text { Mr Gauke: The hon. Gentleman says that work does not pay. (meta- } \\
\text { statement) Let us be clear: universal credit always means that it is } \\
\text { worth working an extra hour and worth taking a pay rise (clarifica- } \\
\text { tion). It is always worth working more under universal credit, which } \\
\text { was not the case with the legacy benefits (informing). That is why the } \\
\text { evidence is suggesting that people do work more and do work more } \\
\text { hours than they do under the legacy systems (substantiation) }\end{array}$ & $\begin{array}{l}\text { SM6: (starter) Pre-Head6 }\{\text { Meta- } \\
\text { statement } 6.1\}+(\text { clarifying }+ \\
\text { informing) Head6 }\{\text { Constati- } \\
\text { ve } 6.1+\text { Constative } 6.2\}+(\text { substan- } \\
\text { tiation) Post-Head }\{\text { Constati- } \\
\text { ve } 6.3\}\end{array}$ \\
\hline$\sum_{\infty}^{N}$ & $\begin{array}{l}\text { Stephen Crabb (Preseli Pembrokeshire) (Con): Does my right hon. } \\
\text { Friend agree that one of the reasons why more people have gone out to } \\
\text { work this morning than ever before in our nation's history is that we as } \\
\text { a Government have not ducked the challenge of welfare reform, we do } \\
\text { not let people languish for years on out-of-work benefits, and universal } \\
\text { credit is an essential part of the welfare reform programme? (inviting) }\end{array}$ & $\begin{array}{l}\text { SM7: (inviting) Head7 }\{\text { Quesi- } \\
\text { tive } 7.1\}\end{array}$ \\
\hline$\sum_{\infty}^{\infty}$ & $\begin{array}{l}\text { Mr Gauke: My right hon. Friend is absolutely right (agreement). } \\
\text { It has been the consistent policy of this Government-including under } \\
\text { my predecessors, such as my right hon. Friend-to ensure that we have } \\
\text { a welfare system that puts work at the heart of it. That is one of the } \\
\text { reasons why we have record levels of employment, as he so rightly says } \\
\text { (substantiation) }\end{array}$ & $\begin{array}{l}\text { SM8: (agreement) Pre-Head8 } \\
\text { \{Constative } 8.1\}+(\text { substantiation }) \\
\text { Head8 }\{\text { Constative } 8.2+\text { Consta- } \\
\text { tive } 8.3\}\end{array}$ \\
\hline
\end{tabular}




\begin{tabular}{|c|c|c|}
\hline$\sum_{\infty}^{O}$ & $\begin{array}{l}\text { Luke Graham (Ochil and South Perthshire) (Con): No. 7, Mr Speaker } \\
\text { (requesting) }\end{array}$ & $\begin{array}{l}\text { SM9: (addressing + requesting) } \\
\text { Head9 \{Requestive9.1\} }\end{array}$ \\
\hline$\sum_{\infty}$ & $\begin{array}{l}\text { Mr Speaker: No, the hon. Gentleman was standing up on No. } 1 \text { and he } \\
\text { has a very similar question, so he can unburden himself of his impor- } \\
\text { tant thoughts now (disagreement) }\end{array}$ & $\begin{array}{l}\text { SM10: (disagreement) Head10 } \\
\{\text { Performative } 10.1\}\end{array}$ \\
\hline$\sum_{\infty}$ & $\begin{array}{l}\text { Luke Graham (Ochil and South Perthshire) (Con): My right hon. } \\
\text { Friend is aware that I and many of my Conservative colleagues have } \\
\text { pressed him on the issue of providing support for people during the six- } \\
\text { week assessment and transition periods for universal credit (inform- } \\
\text { ing). Will he confirm that job centres in Scotland will proactively offer } \\
\text { such advances and support where needed? (requesting) }\end{array}$ & $\begin{array}{l}\text { SM11: (informing) Pre-Head10 } \\
\text { \{Meta-statement } 11.1\}+(\text { request- } \\
\text { ing) Head10 }\{\text { Requestive } 11.1)\end{array}$ \\
\hline$\sum_{\infty}^{N}$ & $\begin{array}{l}\text { Mr Gauke: My hon. Friend is right to highlight that point (agreement). } \\
\text { As I said last week, we are refreshing the guidance to DWP staff to en- } \\
\text { sure that people who need support-who will struggle to get through to } \\
\text { the end of the assessment period without financial support-have access } \\
\text { to that money quickly. Increasing the eligibility for advance payments } \\
\text { is one of the best ways in which we can address some of the concerns } \\
\text { that have been raised and learn from that experience. (informing) }\end{array}$ & $\begin{array}{l}\text { SM12: (agreement) Pre-Head11 } \\
\text { \{Constative } 12.1+\text { Meta-statement } \\
12.1\}+(\text { informing) Head11 }\{\text { Con- } \\
\text { stative } 12.2\}\end{array}$ \\
\hline
\end{tabular}

http://hansard.parliament.uk/Commons/2017-10-09/debates/85FA4177-36D2-4D64-876F-B072176F962B/UniversalCredit

Further stage of discourse analysis implies researching the ST according to the presence of its components. The following table shows a vertical structure of ST illustrated in Example 1in terms of Pre-Head, Head, and Post-Head presence and logical relations of SAs and micro-topics to one another:

Table 3

\begin{tabular}{|c|c|c|c|c|c|c|}
\hline \multirow{2}{*}{ SM } & \multicolumn{2}{|c|}{ Pre-Head } & \multicolumn{2}{|c|}{ Head } & \multicolumn{2}{|c|}{ Post-Head } \\
\hline & $\begin{array}{l}\text { Speech } \\
\text { intention }\end{array}$ & $\begin{array}{l}\text { Corresponding } \\
\text { SA }\end{array}$ & $\begin{array}{l}\text { Speech } \\
\text { intention }\end{array}$ & $\begin{array}{l}\text { Corresponding } \\
\text { SA }\end{array}$ & $\begin{array}{l}\text { Speech } \\
\text { intention }\end{array}$ & $\begin{array}{l}\text { Corresponding } \\
\text { SA }\end{array}$ \\
\hline SM1 & & & Questioning & Quesitive1 & & \\
\hline SM2 & & & Answer & Constative 2.1 & substantiation & $\begin{array}{l}\text { Constative } 2.2+ \\
\text { Constative } 2.3\end{array}$ \\
\hline SM3 & agreement & Constative 3.1 & Informing & $\begin{array}{l}\text { Constative } 3.2+ \\
\text { Constative } 3.3\end{array}$ & $\begin{array}{l}\text { inviting }+ \\
\text { requesting }\end{array}$ & $\begin{array}{l}\text { Requestive } 3.1+ \\
\text { Requestive } 3.2\end{array}$ \\
\hline SM4 & clarifying & Meta-statement 4.1 & Statement & $\begin{array}{l}\text { Constative } 4.1+ \\
\text { Constative } 4.2\end{array}$ & & \\
\hline SM5 & informing & $\begin{array}{l}\text { Constative } 5.1+ \\
\text { Constative } 5.2\end{array}$ & Questioning & Quesitive 5.1 & questioning & Quesitive 5.1 \\
\hline SM6 & replying & Meta-statement 6.1 & $\begin{array}{l}\text { clarifying }+ \\
\text { informing }\end{array}$ & $\begin{array}{l}\text { Constative } 6.1+ \\
\text { Constative } 6.2\end{array}$ & substantiation & Constative 6.3 \\
\hline SM7 & & & Inviting & Quesitive 7.1 & & \\
\hline SM8 & agreement & Constative 8.1 & $\begin{array}{l}\text { informing }+ \\
\text { substantiation }\end{array}$ & $\begin{array}{l}\text { Constative } 8.2+ \\
\text { Constative } 8.3\end{array}$ & & \\
\hline SM9 & & & Requesting & Requestive9.1 & & \\
\hline SM10 & & & Disagreement & Performative 10.1 & & \\
\hline SM11 & informing & $\begin{array}{l}\text { Meta-statement } \\
11.1\end{array}$ & Requesting & Requestive 11.1 & & \\
\hline SM12 & agreement & $\begin{array}{l}\text { Constative } 12.1 \\
+ \text { Meta-statement } \\
12.1\end{array}$ & Informing & Constative 12.2 & & \\
\hline
\end{tabular}


As can be seen from Table 3, most SMs within this ST are of poly-componential nature, that is include Pre-Head or/and Post-Head components, which is typical for the parliamentary debates procedure. The polylogical architectonics of this type of discourse requires strong linkage between SMs, which contributes to the coherent progression of the discourse. Moreover, within the macro-topic of Universal Credit, it is possible to distinguish between several micro-topics, most of which can be traced by Head-to-Head connection.

Example 2 illustrates another ST with a macrotopic of UK Amphibious Capability discussed on 21 November 2017 in the House of Commons. Unlike to the previous example showing the polylogue of the main participants of the debates, this stretch of discourse is mostly of cumulative (monologue) nature; here the Member of Parliament argues for approval of the defense bill after two previous hearings.

Example 2

\begin{tabular}{|c|c|c|}
\hline$\sum_{\infty}^{E}$ & $\begin{array}{l}\text { Ruth Smeeth (Stoke-on-Trent North) (Lab): I beg to move that the } \\
\text { House has considered UK amphibious capacity (starter) }\end{array}$ & $\begin{array}{l}\text { SM1: (starter) Pre-Head }\{\text { Re- } \\
\text { questive } 1.1\}\end{array}$ \\
\hline$\sum_{\infty}^{N}$ & $\begin{array}{l}\text { It is genuinely a pleasure to serve under your chairmanship, Mr. Gray } \\
\text { (addressing). Let us be clear why we are here today (clarification). In re- } \\
\text { cent months, there has been simply too much speculation on the future of } \\
\text { our amphibious capabilities, from reports of staggering cuts to the nu- } \\
\text { merical strength of our Royal Marines to the apparent proposed sale of } \\
\text { HMS Bulwark and HMS Albion to the Chileans or the Brazilians. All of } \\
\text { that is seemingly without any consideration of why we have those capa- } \\
\text { bilities or what our current commitments are (informing) }\end{array}$ & $\begin{array}{l}\text { SM2: (addressing + clarification) } \\
\text { Pre-Head }\{\text { Performative } 2.1+ \\
\text { Meta-statement } 2.1\}+(\text { inform- } \\
\text { ing) Head }\{\text { Constative } 2.1\}\end{array}$ \\
\hline$\sum_{\infty}^{\infty}$ & $\begin{array}{l}\text { It is clear, not only from the number of Members here on a Tuesday } \\
\text { morning but from the growing concerns that emerged in the media over } \\
\text { the weekend, just how important this issue is to people right across the } \\
\text { House, across our forces and across the country, and why cuts to our } \\
\text { amphibious capabilities are not only strategically bizarre but politically } \\
\text { unwise (informing) }\end{array}$ & $\begin{array}{l}\text { SM3: (informing) Head } \text { Consta- } \\
\text { tive } 3.1\}\end{array}$ \\
\hline$\sum_{\infty}^{ \pm}$ & $\begin{array}{l}\text { I had planned to start the debate with an unusual comment for an Op- } \\
\text { position MP (starter). I wanted to welcome the statement of the Secretary } \\
\text { of State for Defense, as reported in The Sun, that he was seeking an ad- } \\
\text { ditional £2 billion for our armed forces from the Treasury rather than } \\
\text { see our defenses undermined (clarification). However, after yesterday's } \\
\text { reports in the Mail, I find myself a little confused as to whether the Sec- } \\
\text { retary of State thinks we need more resource or not, and whether the } \\
\text { Government recognize that our security may cost more money and that if } \\
\text { we are going to operate on a global stage, we may need a proper military } \\
\text { (informing). Perhaps the Minister would clarify the current thinking of } \\
\text { her new boss for us (inviting) }\end{array}$ & $\begin{array}{l}\text { SM4: (starter }+ \text { clarification) } \\
\text { Pre-Head }\{\text { Constative } 4.1+ \\
\text { Metastatement } 4.1\}+(\text { informing }) \\
\text { Head }\{\text { Constative } 4.2\}+(\text { invit- } \\
\text { ing) Post-head }\{\text { Constative } 4.3\}\end{array}$ \\
\hline$\sum_{\infty}^{n}$ & $\begin{array}{l}\text { As we prepare to leave the European Union, we find ourselves looking } \\
\text { towards an uncertain future in an increasingly turbulent world (inform- } \\
\text { ing). The global order is facing a period of rapid and unprecedented } \\
\text { change, and it seems that the post-cold-war consensus is disintegrating } \\
\text { in front of us. In the last week alone, we have seen coalition talks fail in } \\
\text { Germany and witnessed the long-awaited, if slow-motion, collapse of the } \\
\text { Mugabe regime in Zimbabwe. In the middle east, the proxy war between } \\
\text { Saudi Arabia and Iran has reached terrifying new depths in Yemen, with } \\
\text { knock-on consequences in Iraq, Lebanon and Syria (informing). That is } \\
\text { only in the last seven days (informing) }\end{array}$ & $\begin{array}{l}\text { SM5: (informing) Pre-Head } \\
\{\text { Constative } 5.1\}+\text { (informing) } \\
\text { Head }\{\text { Constative } 5.2+\text { Consta- } \\
\text { tive } 5.3\}+(\text { informing }) \text { Post-Head } \\
\{\text { Constative } 5.4\}\end{array}$ \\
\hline$\sum_{\infty}^{b}$ & $\begin{array}{l}\text { There are other threats we need to ensure we can militate against, from } \\
\text { our counter-Daesh efforts to, most importantly of all and most directly } \\
\text { applicable to today's debate, a resurgent Russian Federation, which-as } \\
\text { you know better than anyone, Mr. Gray (addressing)-poses a renewed } \\
\text { threat to our friends and allies in the High North as well as across east- } \\
\text { ern Europe. Old certainties are disappearing and new threats are com- } \\
\text { ing to the fore (informing). The world is changing, and so is our place } \\
\text { in it (informing) }\end{array}$ & $\begin{array}{l}\text { SM6: (informing }+ \text { addressing)) } \\
\text { Head }\{\text { Constative } 6.1+\text { Consta- } \\
\text { tive } 6.2\}+(\text { informing) Post- } \\
\text { Head }\{\text { Constative } 6.3\}\end{array}$ \\
\hline
\end{tabular}




\begin{tabular}{|c|c|c|}
\hline$\sum_{\infty}^{N}$ & $\begin{array}{l}\text { That is why the timing of this mini defense capability review-which in- } \\
\text { creasingly seems an excuse to cut our military, if the media reports are } \\
\text { anything to go by-is so perverse. At this moment we should be looking to } \\
\text { broaden our capability, not to narrow it; to invest in our armed forces, } \\
\text { not to run them down; and to expand our horizons and our influence, not } \\
\text { to retreat from our commitments (informing) }\end{array}$ & $\begin{array}{l}\text { SM7: (informing) Head }\{\text { Consta- } \\
\text { tive7.1 + Constative } 7.2\}\end{array}$ \\
\hline$\sum_{\infty}^{\infty}$ & $\begin{array}{l}\text { Dr Julian Lewis (New Forest East) (Con): In support of what the hon. } \\
\text { Lady just said, may I remind her that when the former Secretary of } \\
\text { State for Defense came before the Defense Committee, he said that the } \\
\text { reason for the review was an intensification of the threats? (reference } \\
+ \text { inviting) We would therefore expect to have more resources put into } \\
\text { defense, rather than fewer (agreement) }\end{array}$ & $\begin{array}{l}\text { SM8: }(\text { reference }+ \text { inviting }) \text { Head } \\
\text { \{Meta-statement } 8.1+\text { Quesitive } \\
8.1\}+(\text { agreement }) \text { Post-Head } \\
\{\text { Constative } 8.1\}\end{array}$ \\
\hline$\sum_{\infty}^{Q}$ & $\begin{array}{l}\text { Ruth Smeeth: I could not agree more (agreement). At this point, we need } \\
\text { to agree what capabilities we need, and then what the budget should be- } \\
\text { not the other way around (informing). That is what the former Secretary } \\
\text { of State said to us, and that is what we need to do (reference) }\end{array}$ & $\begin{array}{l}\text { SM9: (agreement) Pre-Head } \\
\text { \{Constative } 9.1\}+(\text { informing }) \\
\text { Head }\{\text { Constative } 9.2\}+(\text { refer- } \\
\text { ence) Post-Head }\{\text { Constative } 9.3\}\end{array}$ \\
\hline$\sum_{\infty}^{\varrho}$ & $\begin{array}{l}\text { Mr Kevan Jones (North Durham) (Lab): Does my hon. Friend agree } \\
\text { that the black hole is of the Government's own making (inviting)? In } \\
\text { 2013, they increased the whole great shopping list of new equipment, } \\
\text { with no extra cash to pay for it. It was predicated basically on efficiency } \\
\text { savings and land sales, which have not yet been achieved and will not } \\
\text { be achieved (informing) }\end{array}$ & $\begin{array}{l}\text { SM10: (inviting) Head }\{\text { Quesi- } \\
\text { tive } 10.1\}+ \text { (informing) Post- } \\
\text { Head }\{\text { Constative } 10.1+\text { Consta- } \\
\text { tive } 10.2\}\end{array}$ \\
\hline$\sum_{\infty}$ & $\begin{array}{l}\text { Ruth Smeeth: We need to be very clear about how big the hole is in the } \\
\text { equipment budget (informing). That has not happened yet in terms of invest } \\
\text { to save, what efficiencies will be made and how we are going to pay for } \\
\text { things. However, that is not an excuse to cut the numbers in our military or } \\
\text { to get rid of current capabilities and platforms (informing + concession) }\end{array}$ & $\begin{array}{l}\text { SM11: } \text { (informing) Pre-Head } \\
\{\text { Constative } 11.1\}+\text { (informing } \\
+ \text { concession) Head }\{\text { Constative } \\
11.2+\text { Constative } 11.3\}\end{array}$ \\
\hline
\end{tabular}

https://hansard.parliament.uk/Commons/2017-11-21/debates/5D9E11B2-84F4-4EAA-AB26-89792D8382A9/ UKAmphibiousCapability

Later follows a vertical representation of Example 2 supposed to illustrate the absence/presence of componential constituents of SMs and their pragma-semantic relation to one another. The specific feature of this ST is its marco- and microtopics unity determined by the cumulative nature of the discourse. A direct Head-to-Head connection can be traced through SM2 to SM9 with later shift of micro-topic into discussing a further relat- ed issue. As can be seen from the example, the contents of these SMs refer to the challenges posed by a precarious political situation in the world (look underlined). Another peculiarity of this ST is a seemingly insufficient composition of SM1 consisting only of Pre-Head component, which can be explained by its direct relation to the whole ST rather than only to an adjacent SM2 which contains its own Pre-Head.

\begin{tabular}{|c|c|c|c|c|c|c|}
\hline \multirow[b]{2}{*}{$\sum_{\infty}$} & \multicolumn{2}{|c|}{ Pre-Head } & \multicolumn{2}{|c|}{ Head } & \multicolumn{2}{|c|}{ Post-Head } \\
\hline & $\begin{array}{l}\text { Speech inten- } \\
\text { tion }\end{array}$ & Corresponding SA & $\begin{array}{l}\text { Speech inten- } \\
\text { tion }\end{array}$ & $\begin{array}{l}\text { Corresponding } \\
\text { SA }\end{array}$ & $\begin{array}{c}\text { Speech } \\
\text { intention }\end{array}$ & $\begin{array}{c}\text { Corresponding } \\
\text { SA }\end{array}$ \\
\hline$\sum_{\infty}^{F}$ & starter & Requestive1.1 & & & & \\
\hline$\sum_{\infty}^{3}$ & $\begin{array}{l}\text { addressing + } \\
\text { clarifycation }\end{array}$ & $\begin{array}{l}\text { Performative } 2.1+ \\
\text { Metastatement } 2.1\end{array}$ & informing & Constative 2.1 & & \\
\hline$\sum_{\infty}^{\infty}$ & & & informing & Constative 3.1 & & \\
\hline$\sum_{\infty}^{ \pm}$ & $\begin{array}{l}\text { starter }+ \text { clari- } \\
\text { fication }\end{array}$ & $\begin{array}{l}\text { Constative } 4.1+ \\
\text { Metastatement4.1 }\end{array}$ & informing & Constative 4.2 & inviting & Constative 4.3 \\
\hline$\sum_{\infty}^{\infty}$ & informing & Constative 5.1 & informing & $\begin{array}{l}\text { Constative } 5.2+ \\
\text { Constative } 5.3\end{array}$ & informing & Constative 5.4 \\
\hline$\sum_{\infty}^{\infty}$ & & & $\begin{array}{l}\text { informing + } \\
\text { addressing }\end{array}$ & $\begin{array}{l}\text { Constative } 6.1+ \\
\text { Constative } 6.2\end{array}$ & informing & Constative 6.3 \\
\hline
\end{tabular}




\begin{tabular}{|c|c|c|c|c|c|c|}
\hline$\sum_{\infty}^{N}$ & & & informing & $\begin{array}{l}\text { Constative } 7.1+ \\
\text { Constative } 7.2\end{array}$ & & \\
\hline$\sum_{\infty}^{\infty}$ & $\begin{array}{l}\text { reference + } \\
\text { inviting }\end{array}$ & $\begin{array}{l}\text { Metastatement8.1 + } \\
\text { Quesitive8.1 }\end{array}$ & $\begin{array}{l}\text { reference + } \\
\text { inviting }\end{array}$ & $\begin{array}{l}\text { Metastate- } \\
\text { ment8.1 + Quesi- } \\
\text { tive8.1 }\end{array}$ & agreement & Constative8.1 \\
\hline$\sum_{\mathscr{N}}^{Q}$ & agreement & Constative9.1 & informing & Constative 9.2 & reference & Constative9.3 \\
\hline$\sum_{\infty}^{\ominus}$ & & & Inviting & Quesitive10.1 & informing & $\begin{array}{l}\text { Constative } 10.1+ \\
\text { Constative } 10.2\end{array}$ \\
\hline$\sum_{\infty}$ & informing & Constative 11.1 & $\begin{array}{l}\text { informing + } \\
\text { concession }\end{array}$ & $\begin{array}{l}\text { Constative } 11.2+ \\
\text { Constative } 11.3\end{array}$ & & \\
\hline
\end{tabular}

Example 3 shows another typical stretch of discourse within the framework of Parliamentary debates, the announcement of forthcom- ing business (16 November 2017) which is a ceremonial procedure at the opening of a session.

Example 3

\begin{tabular}{|c|c|c|}
\hline$\sum_{\infty}$ & $\begin{array}{l}\text { Valerie Vaz (Walsall South) (Lab): Will the Leader of the House please } \\
\text { give us the forthcoming business (inviting)? }\end{array}$ & $\begin{array}{l}\text { SM1: (inviting) Head \{Quesi- } \\
\text { tive1.1\} }\end{array}$ \\
\hline$\sum_{\infty}^{N}$ & $\begin{array}{l}\text { The Leader of the House of Commons (Andrea Leadsom): The busi- } \\
\text { ness for next week is as follows (starter): } \\
\text { Monday } 20 \text { November-Motion to approve a Ways and Means resolution } \\
\text { relating to the Taxation (Cross-Border Trade) Bill. } \\
\text { Tuesday } 21 \text { November-Continuation of consideration in Committee of } \\
\text { the European Union (Withdrawal) Bill (day 3) (informing) }\end{array}$ & $\begin{array}{l}\text { SM2: }(\text { starter }) \text { Pre-Head }\{\text { Con- } \\
\text { stative } 2.1\}+ \text { (informing) Head } \\
\{\text { Constative } 2.2+\text { Constative } 2.3\}\end{array}$ \\
\hline$\sum_{\infty}^{\infty}$ & $\begin{array}{l}\text { Mr. Speaker, thank you for sending out notification today of the extension } \\
\text { to the telephone helpline service to include staff of the Commons and of } \\
\text { the other place (performative). This will help ensure that all staff can ac- } \\
\text { cess the counseling support they need, both by phone and in person, and } \\
\text { can raise any grievance or complaint they wish to make. I am sure this } \\
\text { will be widely welcomed across the estate (informing) }\end{array}$ & $\begin{array}{l}\text { SM3: (addressing) Head } \\
\text { \{Performative } 3.1\}+ \text { (informing) } \\
\text { Post-Head }\{\text { Constative } 3.1+ \\
\text { Constative } 3.1\}\end{array}$ \\
\hline$\sum_{\infty}^{ \pm}$ & $\begin{array}{l}\text { I take the opportunity to thank the Members of the Youth Parliament who } \\
\text { filled this Chamber last Friday with energetic and passionate debate (in- } \\
\text { forming). They did themselves proud, and I wish them the best with their } \\
\text { future campaigns (informing) }\end{array}$ & $\begin{array}{l}\text { SM4: (informing) Head }\{\text { Perfor- } \\
\text { mative } 4.1\}+ \text { (informing) Post- } \\
\text { Head }\{\text { Constative } 4.1\}\end{array}$ \\
\hline$\sum_{\infty}^{n}$ & $\begin{array}{l}\text { I also congratulate the thousands of organizations hosting UK Parlia- } \\
\text { ment Week events this week (informing). I had an excellent evening with } \\
\text { the Wootton scouts in my constituency to answer their questions on Par- } \\
\text { liament, and I am sure many colleagues have had and will have similar } \\
\text { events (informing) }\end{array}$ & $\begin{array}{l}\text { SM5: (informing) Head }\{\text { Per- } \\
\text { formative } 5.1\}+ \text { (informing) } \\
\text { Post-Head }\{\text { Constative } 5.2+ \\
\text { Constative } 5.3\}\end{array}$ \\
\hline$\sum_{\infty}^{\infty}$ & $\begin{array}{l}\text { Mr. Speaker: I completely endorse what the Leader of the House has } \\
\text { just said about the sitting of the UK Youth Parliament last Friday, about } \\
\text { which I hope I was suitably expansive and congratulatory at the time. } \\
\text { I also echo what she said about Parliament Week. I am glad that she } \\
\text { herself has invested in it and derived satisfaction from it }\end{array}$ & $\begin{array}{l}\text { SM6: (agreement }+ \text { informing) } \\
\text { Head \{Performative6.1 + Con- } \\
\text { stative6.1 + Constative } 6.2\}\end{array}$ \\
\hline$\sum_{\mathscr{S}}^{N}$ & $\begin{array}{l}\text { Valerie Vaz (Walsall South) (Lab): I thank the Leader of the House for } \\
\text { the forthcoming business (informing). I note that next Tuesday we have } \\
\text { day three of our consideration of the European Union (Withdrawal) } \\
\text { Bill-cheer! (informing) }\end{array}$ & $\begin{array}{l}\text { SM7: (informing) Head }\{\text { Perfor- } \\
\text { mative } 7.1\}+ \text { (informing) Post- } \\
\text { Head }\{\text { Constative } 7.1\}\end{array}$ \\
\hline$\sum_{\infty}^{\infty}$ & Mr. Peter Bone (Wellingborough) (Con): Hooray! (marker) & $\begin{array}{l}\text { SM8: (marker) Head }\{\text { Interjec- } \\
\text { tion8.1\}}\end{array}$ \\
\hline
\end{tabular}

https:/hansard.parliament.uk/commons/2017-11-16/debates/85674736-C1E8-4263-9E76-FD92D12F5C97/

BusinessOfTheHouse 
Graphic representation of Example 3 indicates that within the macro-topic of announcing forthcoming business, the initiating SMs 1-2 correlate with closing SMs 7-8 whereas interim SMs 3-6 lack obvious cohesion with one another. Each of these SMs contain Performative expressions (look underlined), which is quite typical for this kind of procedure. This type of discourse procession demonstrates loose connection and broken formal ties between the SMs; however, the general structure of SE looks unified because SMs are embedded into it by illocutionary force, which brings coherence to this stretch of discourse.

\begin{tabular}{|c|c|c|c|c|c|c|}
\hline \multirow[b]{2}{*}{ SM } & \multicolumn{2}{|c|}{ Pre-Head } & \multicolumn{2}{|r|}{ Head } & \multicolumn{2}{|c|}{ Post-Head } \\
\hline & $\begin{array}{c}\text { Speech } \\
\text { intention }\end{array}$ & Corresponding SA & $\begin{array}{c}\text { Speech } \\
\text { intention }\end{array}$ & Corresponding SA & $\begin{array}{c}\text { Speech } \\
\text { intention }\end{array}$ & $\begin{array}{l}\text { Corresponding } \\
\text { SA } \\
\end{array}$ \\
\hline SM1 & & & inviting & Quesitive 1.1 & & \\
\hline SM2 & starter & Constative2.1 & informing & $\begin{array}{l}\text { Constative } 2.2+\text { Con- } \\
\text { stative } 2.3\end{array}$ & & \\
\hline SM3 & & & addressing & Performative 3.1 & informing & $\begin{array}{l}\text { Constative } 3.1+ \\
\text { Constative } 3.2\end{array}$ \\
\hline SM4 & & & informing & Performative 4.1 & informing & Constative 4.1 \\
\hline SM5 & & & informing & Performative 5.1 & informing & $\begin{array}{l}\text { Constative } 5.1+ \\
\text { Constative } 5.2 \\
\end{array}$ \\
\hline SM6 & & & $\begin{array}{l}\text { agreement }+ \\
\text { informing }\end{array}$ & $\begin{array}{l}\text { Constative } 6.1+\text { Con- } \\
\text { stative } 6.2+\text { Consta- } \\
\text { tive } 6.3+\end{array}$ & & \\
\hline SM7 & & & informing & Performative 7.1 & informing & Constative 7.1 \\
\hline SM8 & & & marker & Interjection 8.1 & & \\
\hline
\end{tabular}

The examples presented above illustrate three distinctive types of British Parliamentary discourse as for their general pragmatic organization: the first exemplifies the debates itself; the second is peculiar for a report and subsequent discussion; the third is dominating in the boundaries of ceremonial procedures. As these types of discourse actually make the procedure of Parliamentary debates, the results yielded by the analysis can be extrapolated to the whole discourse of the British Parliament.

\section{Conclusions}

An extended pragmalinguistic analysis of British Parliamentary discourse enabled us to make the following conclusions: this type of discourse possesses distinctive features of coherence and cohesion within each ST, even if some SMs may lack obvious connection with one another (Example 3 ), this does not break the general unity of the discourse because the relation of "loose" SMs to the macro-topic can be easily traced. Sometimes, there can occur mono-componential non-nuclear SMs (Example 2, SM 1) if they serve as a starter or marker element to the further developing ST. Theme procession of the discourse usually goes in Head-to-Head connection (93\%).

According to discourse architectonics, polycomponential SMs make up $68 \%$ of speech activity within the Parliamentary debates, with a relatively even distribution between those of full composition $($ Pre-Head + Head + Post-Head $)-22 \%$; Pre-Head + Head $-24 \%$; Head + Post-Head $-22 \%$. The proportion of mono-componential SMs (typically, consisting of a Head component) is $32 \%$. The prevailing number of poly-componential SMs is regarded to the speech maxim dictated by pragmatic norms of speech activity in the British Parliament to furnish speech intentions with necessary linkage between its constituents, which contributes to coherent and cohesive procession of the discourse.

From the point of view of pragmatic composition, poly-headed SMs (those consisting of more than one SA) make up $70 \%$ of utterances within the discourse of British Parliamentary debates; the other $30 \%$ constitute mono-headed SA which typically express the pragmatic intention of informing (Constatives), requesting (Requestives) or expressing verbal action (Performatives).

According to the general distribution of SAs, Constatives make the most frequently used class of SAs with a portion of $80 \%$, Performatives $-7 \%$, Promisives $-4 \%$, Requestives $-4 \%$, Meta-statements $-3 \%$, Quesitives - $2 \%$. As for binary division, typical is the occurrence of positively-oriented SAs (Positives, Requestives, Promisives), which also makes a firmly set norm of speech activity in the House of Commons of the British Parliament as one of the oldest legal institution in the world. 


\section{References}

Зернецький П. В. Основні контент-аналітичні характеристики Британського парламентського дискурсу (на матеріалі дебатів у палаті громад) / П. В. Зернецький, Г. Л. Рябоконь // Магістеріум. Мовознавчі студії. - 2014. - Вип. 57. - С. 33-36.

Карабан В. И. Сложные речевые акты как речевые единицы дис. ... докт. филол. наук : 10.02.19 / В. И. Карабан. - Киев, 1989.

Остин Дж. Л. Слово как действие / Дж. Л. Остин ; перевод с английского А. А. Медниковой // Новое в зарубежной лингвистике. - Москва : Прогресс, 1986. - Вып. XVII: Теория речевых актов. - С. 22-129.

Почепцов О. Г. Основы грамматического описания предложения / О. Г. Почепцов. - Киев : Вища школа, 1986.

Рябоконь Г. Л. Дискурсивні особливості інтернет-публікацій дебатів британського парламенту : дис. ... канд. філол. наук : 10.01.08 / Ганна Леонідівна Рябоконь ; Національний ун-т «Києво-Могилянська академія». - Київ, 2005.

Серажим К. Дискурс як соціолінгвальне явище: методологія, архітектоніка, варіативність [На матеріалах сучасної газетно публіцистики] : монографія / К. Серажим ; за ред. В. Різуна ; Київ. нац. ун-т ім. Тараса Шевченка. - Київ, 2002. - 392 с.

Серль Дж. Р. Косвенные речевые акты / Дж. Р. Серль ; перевод с английского Н. В. Перцова // Новое в зарубежной лингвистике. - Москва : Прогресс, 1986а. - Вып. XVII: Теория речевых актов. - С. 195-318.
Серль Дж. Р. Классификация иллокутивных актов / Дж. С. Серль ; перевод с английского 3. Демьянкова // Новое в зарубежной лингвистике. - Москва : Прогресс, 1986б. - Вып. XVII: Теория речевых актов. - С. 170-194.

Bik-May Tsui Amy. The Description of Utterances in Conversations [Electronic resource] / Amy Bik-May Tsui // Pragmatics at Issue: Selected papers on the International Pragmatics Conference, Antwerp, August 17-22, 1987, Vol. 1. J. Verschuren (Ed.). - Mode of access: https://books.google.com.ua/books?id =9W1CAAAAQBAJ\&pg=PA237\&lpg=PA237\&dq=pragmatic $\mathrm{s}+$ Pre-head + head + post-head \&source $=$ bl\&ots $=$ uxwpXKGOs 8 $\&$ sig $=$ X7KabxXVQ7QmpW1iurMMkjma8Y4\&hl=ru\&sa=X\& ved=0ahUKEwi7 fo9zWAhVDKpoKHQpxC9kQ6AEIJjAA $\# \mathrm{v}=$ onepage \& $\mathrm{q}=$ pragmatics $\% 20$ Pre-head\%20head\%20posthead $\& \mathrm{f}=$ false. - Title from the screen.

Dijk T. A. van. The Study of Discourse / T. A. van Dijk // Discourse Studies: A Multidisciplinary Introduction. - London, Great Britain : SAGE Publications, 1987. - Vol. 1. - P. 1-34.

Frazer B. Hedged Performatives / B. Frazer // Syntax and Semantics. - 1975. - Vol. 3 : Speech Acts. - P. 187-210.

Searle J. R. Speech Acts / J. R Searle. - Cambridge : Cambridge University Press, 1969.

Sinclair J. Towards an analysis of discourse / J. Sinclair, M. Coulthard // Coulthard M. Advance in Spoken Discourse Analysis. London and New York : Routledge, 1992.

\section{Павло Зернецький, Ганна Рябоконь}

\section{ОРГАНІЗАЦИЙНА СТРУКТУРА БРИТАНСЬКОГО ПАРЛАМЕНТСЬКОГО ДИСКУРСУ: ПРАГМАЛІНГВІСТИЧНИЙ АСПЕКТ}

Стаття досліджує особливості побудови висловлювань у британському парламентському дискурсі з позицій прагмалінгвістики. За основу дослідження автори беруть класифікацію мовленнсвих актів Дж. Остіна та Дж. Серля, об'єднану з моделлю аналізу усного дискурсу Дж. Сінклера та М. Култхарда, і застосовують ії для описання складових компонентів мовленнєвих кроків (Перед-ядро, Ядро, Після-ядро) у мовленнєвій діяльності основних учасників британських парламентських дебатів. Автори визначають прагматичні наміри мовиів та описують модель прогресії мовленнєвих кроків ичодо зв язків між Перед-ядерним, Ядерним та Після-ядерним компонентами. Це дає розуміння того, як мовиі будують висловлювання для реалізації своїх мовленнєвих намірів. Автори доповнили модель дискурс-аналізу мовленнєвої комунікації у класі, розроблену Джс. Сінклером та М. Култхардом, відповідними мовленнсвими актами, якими реалізуються різні мовленнєві наміри, й застосували модель для аналізу трьох уривків дискурсу, які демонструють типові для стін парламенту обговорення: власне дебати, представлення законопроекту та цуеремоніальне оголошення порядку денного. Уривки дискурсу, шьо в термінах прагмалінгвістики відповідають мовленнєвим взаємодіям, аналізувались ичодо наявності складових компонентів та типів зв'язків між ними. Було визначено, щчо британському парламентському дискурсу притаманні полікомпонентні мовленнєві акти, тобто ті, щу містять Перед-ядро та/або Після-ядро, щуо забезпечує цуілісність та зв язність дискурсу і є однією з максим мовлення у изьому законодавчому зібранні. Також характерною рисою є багатоядерність мовленнєвих ходів, тобто наявність декількох мовленнєвих актів, які своєю чергою можуть бути моноядерними й позначати однаковий мовленнєвий намір, наприклад, поінформувати, ш⿻ може бути виражене низкою констативів або поліядреними, тобто реалізовувати декілька мовленнєвих намірів, як-от висловити вдячність і поставити запитання (перформатив + квеситив). Найпоширенімим типом зв'язку між компонентами мовленнєвих ходів у британському парламентському дискурсі є зв 'язок міжс їхіми ядрами, а найбільи притаманним мовленнєвим актом є констативи.

Ключові слова: прагматика, мовленнєвий акт, мовленнєвий хід, мовленнєва взаємодія, мовленнєва подія, ілокутивна сила, Перед-ядро, Ядро, Після-ядро. 